University of Nebraska - Lincoln

DigitalCommons@University of Nebraska - Lincoln

Interferon Gamma Enhances Proteasome Activity in Recombinant Hep G2 Cells that Express Cytochrome P4502E1: Modulation by Ethanol

\author{
Natalia A. Osna \\ Liver Study Unit, Research Service (151), The Veterans Affairs (VA) Medical Center, University of Nebraska \\ Medical Center, 4101 Woolworth Ave., Omaha, NE 68105-8090, USA \\ Dahn L. Clemens \\ Liver Study Unit, Research Service (151), The Veterans Affairs (VA) Medical Center, University of Nebraska \\ Medical Center, 4101 Woolworth Ave., Omaha, NE 68105-8090, USA \\ Terrence M. Donohue Jr. \\ Liver Study Unit, Research Service (151), The Veterans Affairs (VA) Medical Center, University of Nebraska \\ Medical Center, 4101 Woolworth Ave., Omaha, NE 68105-8090, USA
}

Follow this and additional works at: https://digitalcommons.unl.edu/publichealthresources

Part of the Public Health Commons

Osna, Natalia A.; Clemens, Dahn L.; and Donohue Jr., Terrence M., "Interferon Gamma Enhances Proteasome Activity in Recombinant Hep G2 Cells that Express Cytochrome P4502E1: Modulation by Ethanol" (2003). Public Health Resources. 58.

https://digitalcommons.unl.edu/publichealthresources/58

This Article is brought to you for free and open access by the Public Health Resources at DigitalCommons@University of Nebraska - Lincoln. It has been accepted for inclusion in Public Health Resources by an authorized administrator of DigitalCommons@University of Nebraska - Lincoln. 


\title{
Interferon gamma enhances proteasome activity in recombinant Hep G2 cells that express cytochrome P4502E1: modulation by ethanol
}

\author{
Natalia A. Osna ${ }^{\text {a,b,** }}$, Dahn L. Clemens ${ }^{\mathrm{a}, \mathrm{b}, \mathrm{d}}$, Terrence M. Donohue Jr. ${ }^{\mathrm{a}, \mathrm{b}, \mathrm{c}}$ \\ ${ }^{a}$ Liver Study Unit, Research Service (151), The Veterans Affairs (VA) Medical Center, University of \\ Nebraska Medical Center, 4101 Woolworth Ave., Omaha, NE 68105-8090, USA \\ ${ }^{\mathrm{b}}$ Department of Internal Medicine, University of Nebraska Medical Center, Omaha, NE 68198-4350, USA \\ ${ }^{\mathrm{c}}$ Department of Biochemistry/Molecular Biology, University of Nebraska Medical Center, Omaha, NE 68198-4525, USA \\ ${ }^{\mathrm{d}}$ Department of Pathology/Microbiology, University of Nebraska Medical Center, Omaha, NE 68105-8090, USA
}

Received 17 January 2003; accepted 10 March 2003

\begin{abstract}
We tested the influence of IFN $\gamma$ on proteasome activity in parental Hep G2 cells that do not metabolize ethanol, as well as in recombinant Hep G2-derived cells that express either or both alcohol dehydrogenase (ADH) and cytochrome P4502E1 (CYP2E1). IFN $\gamma$ treatment increased proteasome activity in VL-17A $\left(\mathrm{ADH}^{+}, \mathrm{CYP} 2 \mathrm{E} 1^{+}\right)$and E-47 $\left(\mathrm{CYP} 2 \mathrm{E} 1^{+}\right)$cells, but not in Hep G2, VI-R2 (parental cells with empty vectors) or in VA-13 $\left(\mathrm{ADH}^{+}\right)$cells. Proteasome activation by IFN $\gamma$ correlated positively with the level of CYP2E1 activity. Treatment of VL-17A cells with agents that inhibit CYP2E1 or the inducible nitric oxide synthase (iNOS) or that prevent the formation of peroxynitrite also blocked proteasome activation by IFN $\gamma$, indicating that the proteasome may be directly activated by products of CYP2E1 and iNOS catalysis. While IFN $\gamma$ treatment increased proteasome activity, it also decreased CYP2E1 activity. Both effects were mediated via the Janus kinase-signal transducer and activator of transcription 1 (JAK-STAT1) pathway, as both were blocked by the JAK2 inhibitor, tyrphostin AG 490. Ethanol treatment of VL-17A cells also caused a similar blockage of these same IFN $\gamma$-mediated effects, by inhibiting STAT1 phosphorylation. This inhibition was largely due to ethanol metabolism, as 4-methylpyrazole, an ethanol metabolism inhibitor, restored IFN $\gamma$-mediated STAT1 phosphorylation in ethanol-treated cells. Our results lead us to propose that IFN $\gamma$ initiates signal transduction, which alters the activities of CYP2E1 and iNOS, thereby producing reactive oxygen species. One of these oxidants, possibly peroxynitrite, may be directly involved in proteasome activation. Ethanol metabolism by VL-17A cells suppresses IFN $\gamma$-mediated induction of proteasome activity, in part, by preventing STAT1 phosphorylation.
\end{abstract}

Keywords: Proteasome; Signal transduction; STAT1; Ethanol metabolism; Interferon gamma

\section{Introduction}

The proteasome is a large proteolytic particle that contains multiple catalytic activities for protein degradation. The proteasome participates in the regulation of normal physiological processes in cells, by degrading short-lived

\footnotetext{
* Corresponding author. Tel.: +1-402-346-8800x3576; fax: +1-402-449-0604.

E-mail address: natalia_osna@hotmail.com (N.A. Osna).

Abbreviations: IFN $\gamma$, interferon gamma; $\mathrm{ADH}$, alcohol dehydrogenase; CYP2E1, cytochrome P4502E1; DMEM, Dulbecco's modified Eagle medium; FBS, fetal bovine serum; FLF-AFC, methoxysuccinyl-phe-leu-phe7-amido-4-trifluoromethyl coumarin; IFN $\gamma \mathrm{R} \alpha$, interferon gamma receptor $\alpha$; JAK-STAT1, Janus kinases-signal transducer and activator of transcription 1; DAS, diallyl sulfide; 4-MP, 4-methylpyrazole; NO, nitric oxide.
}

regulatory proteins that have roles in vital cellular functions including proliferation and apoptosis, as well as degrading long-lived constitutive enzymes. The proteasome also has an important role in cellular defense by degrading damaged, potentially cytotoxic proteins [1-4]. Thus, the proteasome is vital for many important cell functions $[5,6]$. The enzyme particle is also involved in antigen presentation [7]. The specific subunits of the immunoproteasome, cleave proteins to distinct peptides, which form complexes with major histocompatibility complex (MHC) class I molecules on the cell surface. These complexes can be recognized by cytotoxic T-lymphocytes (CTLs) that eliminate target cells with foreign peptide repertoires [8]. Any MHC class $\mathrm{I}^{+}$host cell, including the hepatocyte, may be targeted by CTLs $[9,10]$. 
The liver is the primary site of ethanol oxidation, and this organ sustains significant damage from chronic ethanol consumption [11]. In vitro studies using Hep G2-derived cells have demonstrated that ethanol-induced cytotoxicity depends on the levels of expression of the ethanol-metabolizing enzymes, CYP2E1 or ADH $[12,13]$ and therefore, on the levels of ethanol oxidation. There is evidence that metabolites generated from ethanol oxidation can exert inhibitory effects on a number of cellular pathways including the activity of the proteasome. In hepatocytes of patients with alcohol-induced liver disease, Mallory bodies are typical histological hallmarks [14]. These are believed to form as a result of compromised proteasome function or even proteasome depletion [15]. Ethanol consumption can cause reduced hepatic proteasome activity. This effect is associated with high blood ethanol levels in vivo when ethanol is administered by continuous intragastric feeding, which, also results in increased hepatic lipid peroxidation (oxidative stress) [16,17]. Impaired proteasome function appears to result from ethanol metabolism [18]. Pro-inflammatory cytokines, including IFN $\gamma$, are natural modulators of proteasome activity [19]. IFN $\gamma$ acts on a cell by binding to surface IFN $\gamma$ receptors, which initiate the transduction of signals to nuclear genes via the JAK-STAT1 pathway. This occurs by phosphorylation of STAT1, which is then translocated to the nucleus and binds to DNA, initiating downstream effects, which include the modulation of proteasome function in antigen-presenting cells, such as macrophages and dendritic cells $[20,21]$. However, the effect of IFN $\gamma$ on proteasome activity in liver cells has not been characterized.

The aim of this work was to study the response of the proteasome to IFN $\gamma$ and the transduction of IFN $\gamma$ signals in recombinant Hep G2 cells incubated in the presence or absence of ethanol. We tested the influence of IFN $\gamma$ on proteasome chymotrypsin-like activity in parental Hep G2 cells that do not metabolize ethanol, as well as in recombinant Hep G2-derived cells that express either or both ADH and CYP2E1. We also determined whether ethanol itself or the products of its metabolism altered the responsiveness of the proteasome to IFN $\gamma$. We found that IFN $\gamma$ treatment enhanced proteasome activity via the JAKSTAT1 pathway and that this enhancement occurred only in CYP2E1-expressing cells. Here, we provide evidence that this effect may be mediated by peroxynitrite. We further show that prior exposure of cells to ethanol prevented the IFN $\gamma$-induced increase in proteasome activity by blocking STAT1 phosphorylation. Portions of this work have been described in recent abstracts [22,23].

\section{Materials and methods}

\subsection{Reagents and media}

High glucose Dulbecco's modified Eagle medium (DMEM) and fetal bovine serum (FBS) were purchased from Invitrogen. The membrane-permeable flourogenic proteasome substrate, methoxysuccinyl-phe-leu-phe7-amido-4-trifluoromethyl coumarin (FLF-AFC) was obtained from Enzyme Systems Products. Human recombinant IFN $\gamma$ was from PeproTech, Inc. Anti-IFN $\gamma$ R $\alpha$ was from PharMingen. The antibody preparations to phosphorylated signal transducer and activator of transcription 1 (pSTAT1) and STAT1 were from Cell Signaling and from Santa Cruz Biotechnology, Inc., respectively. Diallyl sulfide (DAS), tyrphostin AG 490, and succinyl-Leu-Leu-ValTyr-7-amino-4-methylcoumarin (Suc-LLVY-AMC) were purchased from Sigma. $N, \omega$-Nitro-L-arginine methyl ester (L-NAME), epigallocatechin gallate (EGCG), and 6,10,15,20 tetrakis(4-sulfonatophenyl) porphyrinato iron (III) chloride (FeTPPS) were from Calbiochem. All other chemicals used were analytical grade quality.

\subsection{Cell lines}

All cell lines were derived from the human hepatoblastoma cell line Hep G2, which were obtained from the American Type Culture Collection. Cells expressing both ADH and CYP2E1 were developed by transfecting VA-13 $\left(\mathrm{ADH}^{+}\right)$cells with the expression vector pIV-G2. This vector contains the coding region of the human cytochrome $\mathrm{P} 4502 \mathrm{E} 1$ gene. The coding region was kindly provided by Dr. Frank Gonzalez (National Cancer Institute). VA-13 cells were transfected using Lipo TAXI (Invitrogen Corp.) as described by the manufacturer. Recombinant cells were selected in culture medium containing G418 and zeocin, each at $400 \mu \mathrm{g} / \mathrm{mL}$. Clones were isolated, and clonal cell lines established. Clones were expanded and screened for ADH and CYP2E1 activity. One of the resulting clones, designated VL-17A, was used in the present study. These cells were phenotypically identical to VA-13 cells [12] in their ability to metabolize ethanol and generate acetaldehyde, but they also express CYP2E1 at levels that are comparable to those of rat hepatocytes [24]. ${ }^{1}$ As a control cell line, Hep G2 cells were transfected with both empty vectors, pcDNA3.1 and pcDNA3.1/Zeo ${ }^{(+)}$(Invitrogen). These transfected cells were designated VI-R2 cells. CYP2E1-expressing E-47 cells were the kind gift of Dr. A. Cederbaum (Mount Sinai School of Medicine).

\subsection{Alcohol dehydrogenase (ADH) activity}

Cells were washed with phosphate-buffered saline (PBS) and then detached from the plastic by treating with trypsin. Dislodged cells were resuspended in PBS and lysed by sonication. Each lysate was centrifuged at low speed to remove cell debris, and the supernatant was centrifuged for $1 \mathrm{hr}$ at $105,000 \mathrm{~g}$ to sediment the microsome fraction. The supernatant (cytosol) was removed and supplemented with glycerol to a final concentration of $20 \%$ (v/v). ADH activity

\footnotetext{
${ }^{1}$ Donohue et al., manuscript submitted.
} 
in the cytosolic fraction was measured as originally described by Crow et al. [25] and modified by Clemens et al. [26] and normalized for protein concentration. One ADH enzyme unit catalyzed the formation of $1 \mathrm{nmol}$ of NADH (nicotinamide adenine dinucleotide, reduced form) per hour. Specific activity is expressed as units per mg protein.

\subsection{CYP2E1 catalytic activity}

The microsome pellet derived from the 105,000 $\mathrm{g}$ centrifugation was re-suspended in $250 \mu \mathrm{L}$ PBS containing $20 \%$ glycerol. CYP2E1 activity was measured by hydroxylation of $p$-nitrophenol, as described originally by Koop [27] and modified by Chen et al. [28]. In this micro-assay, the mixture had a final volume of $100 \mu \mathrm{L}$ and was incubated for $1 \mathrm{hr}$. Formation of 4-nitrocatechol (4-NC), the reaction product, was measured by absorbance at $515 \mathrm{~nm}$. This was compared to the absorbance obtained using known quantities of 4-nitrocatechol (4-NC). One CYP2E1 enzyme unit catalyzed the formation of $1 \mathrm{nmol} 4-\mathrm{NC} / \mathrm{hr}$. Specific activity is expressed as units per mg protein. Protein concentration was measured by the dye binding technique of Bradford [29] using reagents from Bio Rad.

\subsection{In situ proteasome assay}

The chymotrypsin-like activity of the proteasome was measured by FLF-AFC hydrolysis, which was determined by a modification of the method described previously [30]. Briefly, cells were plated into 24-well plates at a density of $1 \times 10^{5}$ cells/well in DMEM supplemented with appropriate antibiotics and 10\% FBS. After $24 \mathrm{hr}$ of incubation, the medium was replaced with DMEM containing 3\% FBS and $25 \mathrm{mM}$ HEPES. For experiments using ethanol, plates were sealed with adhesive sealing films for micro-plates (ThermalSeal ${ }^{\mathrm{TM}}$, Excel Scientific) to prevent ethanol evaporation. After $72 \mathrm{hr}$ incubation at $37^{\circ}$, the medium was replaced with serum-free DMEM containing $13 \mu \mathrm{M}$ FLFAFC. Fluorescence of AFC was measured every $2 \mathrm{hr}$ on a Fluorolite 1000 plate reader (Dynex Technologies) using excitation and emission filter settings of 390 and $530 \mathrm{~nm}$, respectively. After the last reading, the attached cells were lysed by direct sonication of each well, and samples were taken for the fluorometric measurement of DNA [31], which was used for normalization. Data are expressed as nmole $\mathrm{AFC} / \mu \mathrm{g}$ DNA. Nanomoles of AFC were calculated on the basis of an AFC standard curve. To determine the specificity of proteasome activity with FLF-AFC, cells were treated with $10 \mu \mathrm{M}$ lactacystin, a specific proteasome inhibitor, which caused a $70 \%$ decline in the rate of FLFAFC hydrolysis (data not shown).

\subsection{In vitro proteasome assay}

For in vitro measurements of chymotrypsin-like activity of the proteasome, cells were lysed by sonication in PBS.
Suc-LLVY-AMC hydrolysis using cytosolic fractions of the lysates was tested as described by Donohue et al. [16].

\subsection{Exposure of cells to IFN}

In most cases, cells were exposed to IFN $\gamma(10 \mathrm{ng} / \mathrm{mL})$, for $24 \mathrm{hr}$. In some dose-response and kinetic experiments, the concentration of IFN $\gamma$ varied from 2 to $50 \mathrm{ng} / \mathrm{mL}$, and the duration of treatment varied between 0 and $24 \mathrm{hr}$.

\subsection{Detection of interferon gamma receptor alpha $(I F N \gamma R \alpha)$}

To determine the relative levels of IFN $\gamma \mathrm{R} \alpha$, cells were plated onto 6-well plates at $1 \times 10^{6}$ cells/well in DMEM supplemented with $3 \%$ FBS, $25 \mathrm{mM}$ HEPES and ethanol ( 0 or $100 \mathrm{mM})$. After incubation for $72 \mathrm{hr}$, cells were washed with PBS and detached from the plate using Cellstripper (Cellgro), centrifuged, washed and suspended in blocking buffer (PBS containing $0.1 \%$ sodium azide and $3 \%$ FBS) for 15 min to prevent non-specific binding of protein. Cells $\left(1 \times 10^{6} /\right.$ tube $)$ were incubated in $100 \mu \mathrm{L}$ for 30 min on ice with $1 \mu \mathrm{g}$ of phycoerythrin-conjugated antihuman IFN $\gamma R \alpha$ (PharMingen) and then washed twice in cold PBS. As an isotype control, anti-human IgG-PE antibody (PharMingen), was used. The cells were analyzed with a FACSCAN flow cytometer (Becton Dickinson) to detect bound antibody.

\subsection{Detection of STAT1 and phospho-STAT1}

Cells were plated onto 6-well plates using DMEM with $10 \%$ FBS. After overnight attachment at $37^{\circ}$, the medium was changed to serum-free DMEM with or without $100 \mathrm{mM}$ ethanol, and cells were incubated for $72 \mathrm{hr}$. Cells were treated or not with IFN $\gamma(10 \mathrm{ng} / \mathrm{mL})$, for 1,5 or $24 \mathrm{hr}$. Then, cells were lysed by freezing and thawing using $0.5 \mathrm{~mL}$ of lysis buffer $(40 \mathrm{mM}$ Tris- $\mathrm{HCl}$ ( $\mathrm{pH} 7.4)$, $1 \mathrm{mM}$ EDTA, $10 \mathrm{mM}$ sodium pyrophosphate, $2 \mathrm{mM}$ sodium orthovanadate, $1 \mathrm{mM}$ phenylmethylsulfonyl fluoride, $100 \mathrm{mM}$ sodium fluoride, $1 \%$ Triton $\mathrm{X}-100,2 \mu \mathrm{g}$ aprotinin/mL). A portion of each lysate $(30 \mu \mathrm{g}$ protein/well) was subjected to SDS-PAGE on $12 \%$ gels. Proteins were electrophoretically transferred onto nitrocellulose membranes. Membranes were blocked with $5 \%$ bovine serum albumin (BSA) for $1 \mathrm{hr}$ at room temperature and then incubated overnight at $4^{\circ}$ with anti-phospho-STAT1 (pSTAT1), diluted 1:1000. The membranes were extensively washed with Tris-buffered saline containing $0.1 \%$ Tween 20 (TBS-T), exposed to 5000-fold diluted peroxidase-conjugated, goat anti-rabbit IgG (Jackson ImmunoResearch Laboratories, Inc.), washed and visualized by enhanced chemiluminescence (ECL; Amersham Pharmacia Biotech). The same membranes were then stripped for $30 \mathrm{~min}$ at $50^{\circ}$ in $62.5 \mathrm{mM}$ Tris- $\mathrm{HCl} \mathrm{pH} 6.7,100 \mathrm{mM}$ 2-mecaptoethanol, $2 \%$ sodium dodecyl sulfate. They were 
re-blocked in 5\% dry non-fat milk-TBS-T overnight at $4^{\circ}$ and exposed to anti-STAT1 (1:1000) antibodies for $1 \mathrm{hr}$ at room temperature. Subsequently, the membranes were incubated with peroxidase-conjugated secondary antibodies (1:2000) and visualized by ECL. The bands were quantified by densitometry, and the pSTAT1/STAT1 densitometric ratio was calculated.

\section{A: VL-17A cells}

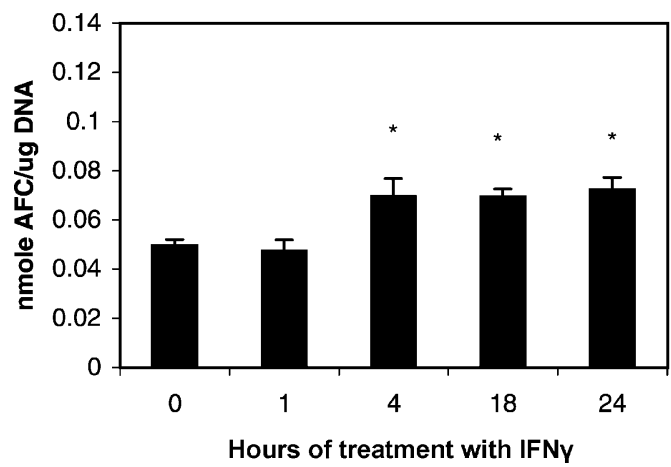

C. VL-17A cells

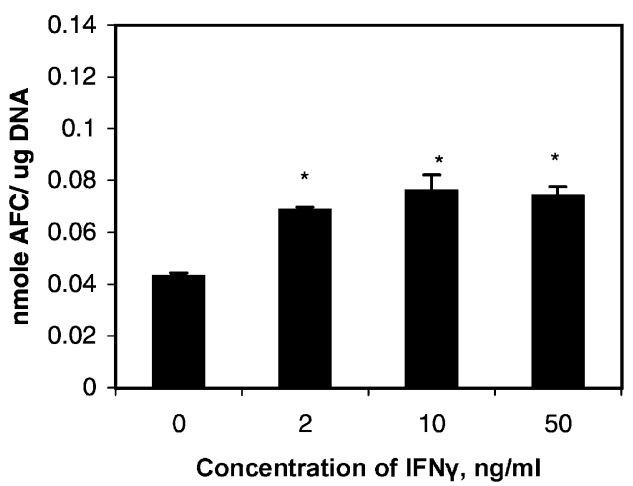

E: VL-17A and VI-R2 cells

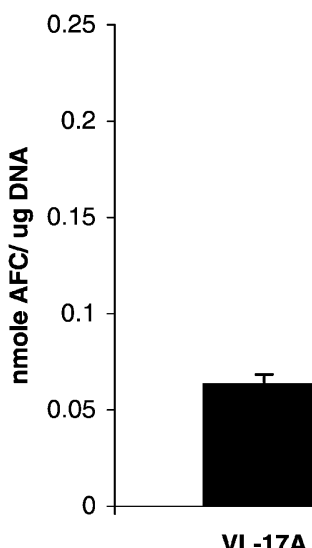

VL-17A

\subsection{Statistical analyses}

Data are expressed as mean values \pm standard deviation. Because the analyzed parameters had a normal distribution, comparisons for significance were determined by Student's $t$-test between two groups or by one-way ANOVA, using a Tukey post-test for multiple comparisons. For correlations,

\section{B. Hep G2 cells}

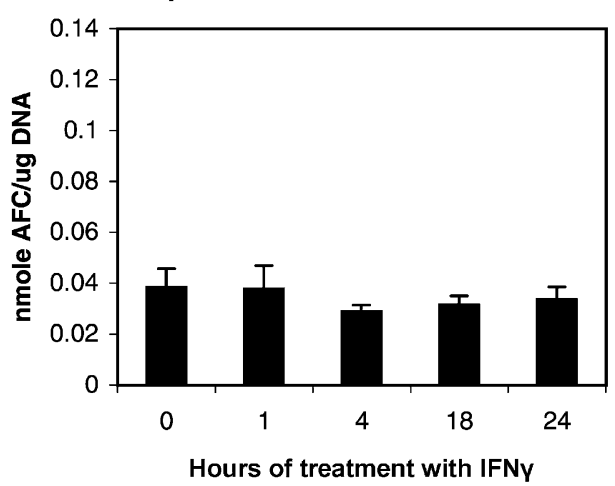

\section{Hep G2 cells}

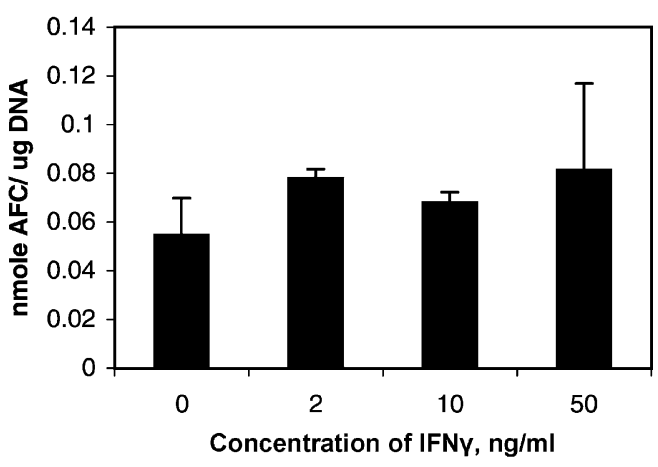

Fig. 1. Effects of IFN $\gamma$ on the chymotrypsin-like activity of the proteasome in ethanol-metabolizing VL-17A and ethanol non-metabolizing Hep G2 and VI$\mathrm{R} 2$ cells. Cells were plated onto 24-well plates and then exposed to IFN $\gamma$ or left untreated. (A and B) Proteasome activity was assayed in situ after various times of exposure to IFN $\gamma(10 \mathrm{ng} / \mathrm{mL})$ in VL-17A cells or Hep G2 cells. (C and D) Proteasome activity after 24 hr exposure to various doses of IFN $\gamma$ in VL17A or Hep G2 cells. (E) Proteasome activity after $24 \mathrm{hr}$ of treatment with IFN $\gamma(10 \mathrm{ng} / \mathrm{mL})$ in VL-17A cells and VI-R2 cells. Data presented are mean values $( \pm \mathrm{SD})$ of proteasome activity (nmol AFC/ $\mu \mathrm{g} \mathrm{DNA}$ ) that were calculated from four independent experiments (quadruplicate measurements in each experiment). Asterisk indicates a significant difference at $P<0.05$ between IFN $\gamma$-treated and -untreated cells. 
Pearson's coefficient of correlation was used. A probability value of 0.05 or less was considered significant.

\section{Results}

To determine whether IFN $\gamma$ affects the activity of the proteasome, we treated VL-17A and VI-R2 and/or Hep G2 cells with various doses of IFN $\gamma(2-50 \mathrm{ng} / \mathrm{mL})$ for $1-24 \mathrm{hr}$. Chymotrypsin-like activity of the proteasome was subsequently tested in situ by FLF-AFC hydrolysis. Exposure to
IFN $\gamma$ increased FLF-AFC hydrolysis by $20-50 \%$ in VL-17A cells compared with their untreated controls. This increase was first detected after $4 \mathrm{hr}$ of treatment with IFN $\gamma$ and remained elevated after $24 \mathrm{hr}$ (Fig. 1A). Proteasome activity in cell lysates or the cytosolic fractions of VL-17A cells assayed in vitro with Suc-LLVY-AMC was increased up to $40 \%$ after treatment with IFN $\gamma$ (not shown). However, proteasome activity in VI-R2 and Hep G2, both ethanol non-metabolizing cells, did not increase in response to IFN $\gamma$ treatment regardless of IFN $\gamma$ dose and time of treatment (Fig. 1B, D and E).

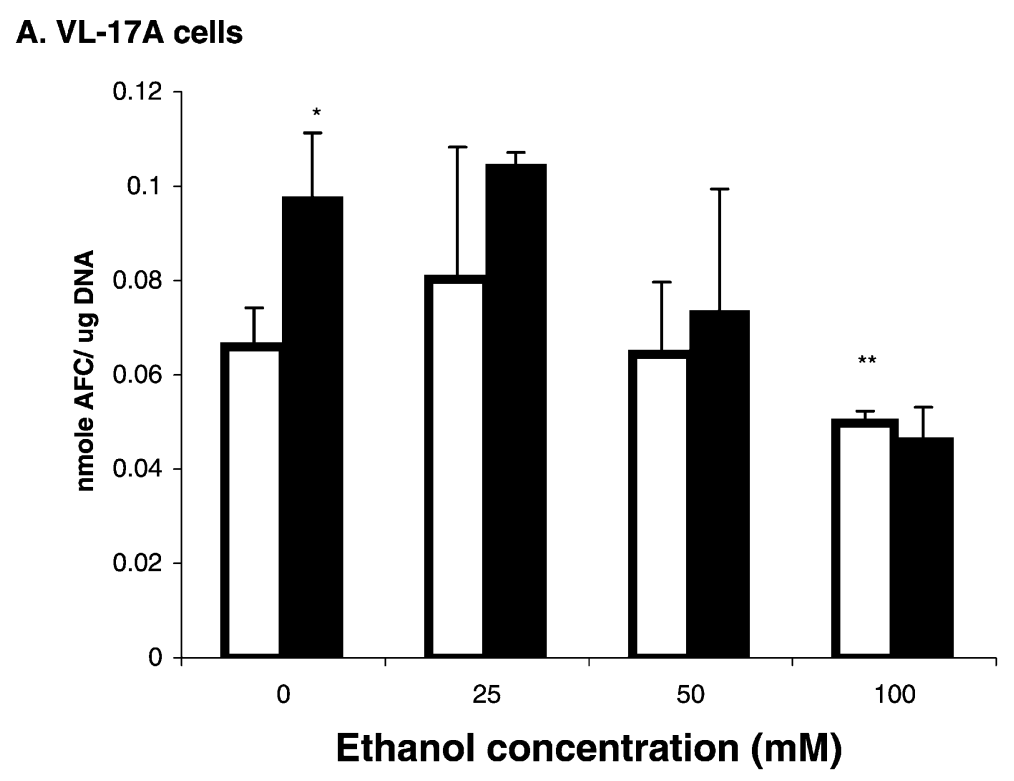

B: VI-R2 cells

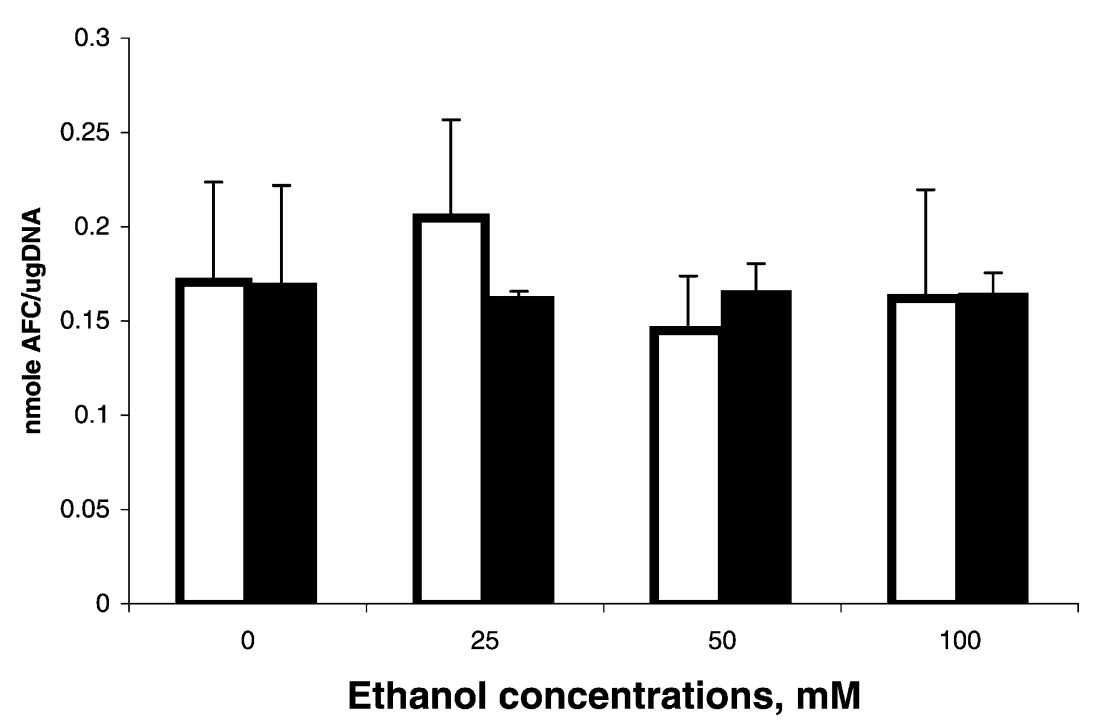

Fig. 2. Effects of ethanol treatment on proteasome activity after IFN $\gamma$ treatment of VL-17A and VI-R2 cells. Cells were exposed to the indicated concentrations. After $48 \mathrm{hr}$ of ethanol exposure, cells were treated or not with IFN $\gamma$ for $24 \mathrm{hr}$. Data represent mean values $( \pm \mathrm{SD})$ of six independent experiments (quadruplicate measurements in each experiment), after $6 \mathrm{hr}$ of incubation with FLF-AFC. Asterisk indicates significant difference between the proteasome activity in the presence (dark bars) or absence of IFN $\gamma$ (open bars). Double asterisks indicate significant difference between ethanol-untreated cells (without exposure to IFN $\gamma$ ) and ethanol-treated cells. 
We examined whether ethanol influenced the activation of the proteasome by IFN $\gamma$. VL-17A and VI-R2 cells were each treated with $0,25,50$ and $100 \mathrm{mM}$ ethanol for $72 \mathrm{hr}$ and then exposed to IFN $\gamma$. Ethanol alone, at all concentrations, had no effect on proteasome activity in Hep G2 cells (not shown), or in VI-R2 cells (data shown in Fig. 2, panel B). However, $100 \mathrm{mM}$ ethanol treatment caused a $30-40 \%$ decrease in proteasome chymotrypsin-like activity in VL-17A cells compared with their untreated controls. Additionally, in VL-17A cells, ethanol, at even lower concentrations ( 25 and $50 \mathrm{mM}$ ) that, by themselves, did not significantly affect FLF-AFC hydrolysis, prevented proteasome activation by IFN $\gamma$ (Fig. 2).

The unresponsiveness of Hep G2 and VI-R2 cells to IFN $\gamma$ (Fig 1B, D and E) was not due to reduced levels or the absence of IFN $\gamma$ receptors on these cells. Flow cytometric analyses revealed that both VI-R2 and VL-17A cells had comparable numbers of IFN $\gamma$ R-positive cells. Non-specific staining with isotype-specific antibodies occurred in less than $0.5 \%$ of cells. Furthermore, there was no indication that treatment with $100 \mathrm{mM}$ ethanol for $72 \mathrm{hr}$ reduced IFN $\gamma \mathrm{R}$ levels in either cell type (Fig. 3).

Because proteasome activity was enhanced by IFN $\gamma$ in VL-17A but not in VI-R2 or Hep G2 cells, we tested the possibility that $\mathrm{ADH}$ and/or CYP2E1 expression may be involved in IFN $\gamma$-induced activation of the proteasome. We treated ADH-expressing VA-13 cells and CYP2E1-expressing E-47 cells with IFN $\gamma$ for $24 \mathrm{hr}$. IFN $\gamma$ treatment enhanced proteasome activity in E-47 cells by $20 \%$ $(P=0.05)$, but it caused no change in proteasome activity in VA-13 cells (Fig. 4), indicating that the IFN $\gamma$-mediated elevation of proteasome activity was related to CYP2E1, but not to ADH expression.

CYP2E1 activity in VL-17A cells was not constant in all experiments. Enzyme activity varied as much as 2-fold between passages. We noted that the magnitude of proteasome activation by IFN $\gamma$ was positively associated with the basal CYP2E1 activity of VL-17A cells before treatment with the cytokine. Statistical determination of such a correlation indeed showed that VL-17A cells with higher CYP2E1 activity had a greater degree of proteasome activation with IFN $\gamma$ than those with lower CYP2E1 activity (Pearson $r=0.9389, P=0.0055$ ). Conversely, pretreatment of cells with $10 \mu \mathrm{M}$ diallyl sulfide (DAS), an inhibitor of CYP2E1 catalytic activity [32], prevented proteasome activation by IFN $\gamma$ (Fig. 5). These data indicate that a product of CYP2E1 catalysis may have a role in proteasome activation following treatment with IFN $\gamma$.

IFN $\gamma$ also increases iNOS activity, which results in the increased production of nitric oxide (NO) [33]. To determine the contribution of IFN $\gamma$-mediated NO formation to proteasome activation, we treated VL-17A cells with IFN $\gamma$ in the presence of the iNOS inhibitors, L-NAME $(300 \mu \mathrm{M})$ and EGCG $(200 \mu \mathrm{M})$ for $24 \mathrm{hr}$. Both agents blocked proteasome activation by IFN $\gamma$ (Fig. 6A and B). These latter data indicated that $\mathrm{NO}$, in addition to the product
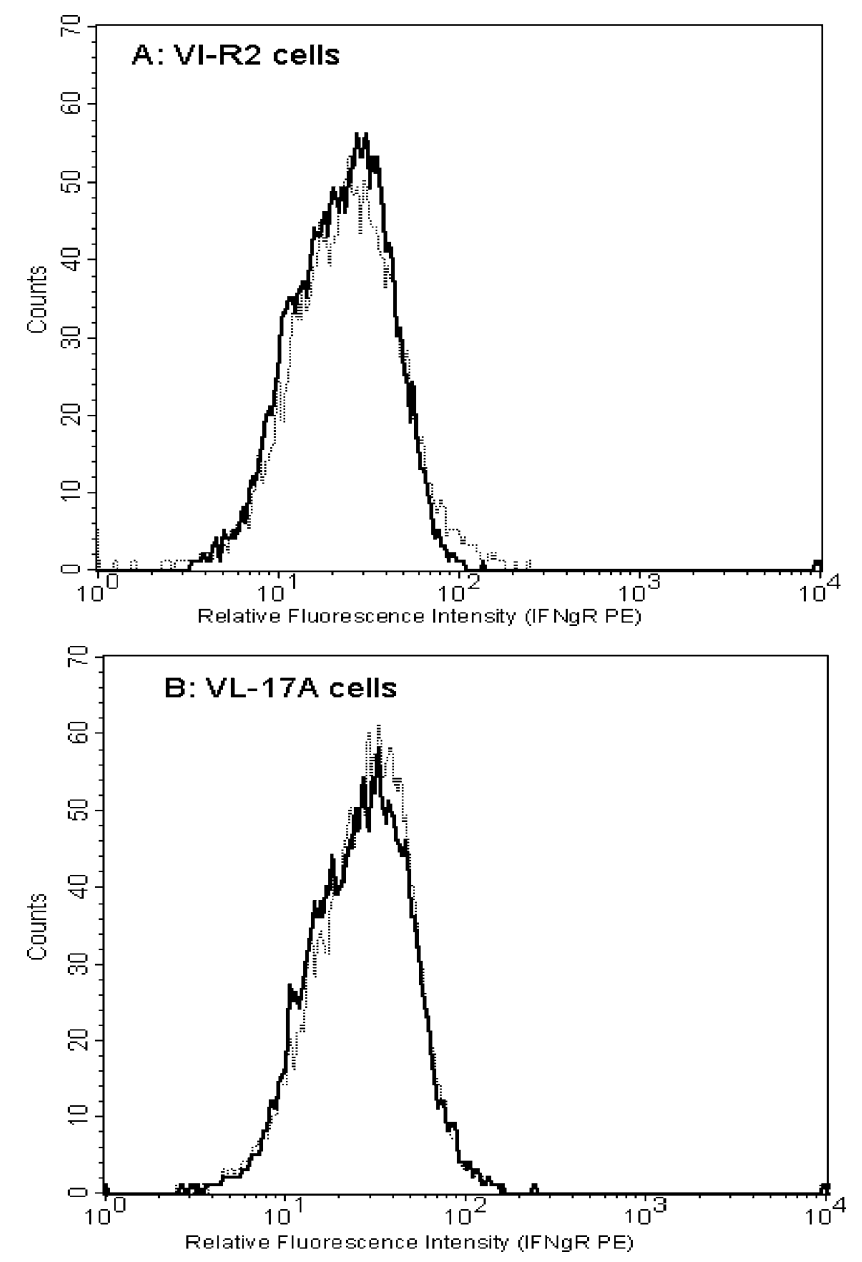

Fig. 3. Flow cytometric analysis of IFN $\gamma$ receptor (IFN $\gamma R \alpha)$ in ethanoltreated and -untreated VL-17A and VI-R2 cells. Cells were treated or not with $100 \mathrm{mM}$ ethanol for $72 \mathrm{hr}$ and then prepared for flow cytometric analysis as described in Section 2. The cells were analyzed by flow cytometry (three independent experiments). The data show a representative scan from one experiment. Panel A: VI-R2 cells, panel B: VL-17A cells; bold line is untreated cells, dashed line is ethanol-treated cells.

derived from CYP2E1 catalysis, participated in IFN $\gamma$ elicited proteasome activation. To test the possibility that peroxyntrite may be the responsible agent, we treated VL-17A cells with IFN $\gamma$ and the peroxynitrite scavenger, FeTPPS $(10 \mu \mathrm{M})$, which converts peroxynitrite to NO [34]. This compound also prevented proteasome activation by IFN $\gamma$ (Fig. 6C).

In accordance with previous findings [35], IFN $\gamma$ treatment of VL-17A cells for $24 \mathrm{hr}$ decreased CYP2E1 activity by $50 \%$. However, exposure of these cells to $100 \mathrm{mM}$ ethanol for $72 \mathrm{hr}$ enhanced CYP2E1 activity up to 5-fold. This effect was slightly, but not significantly attenuated by IFN $\gamma$ (Fig. 7).

To determine whether CYP2E1 and proteasome activities are regulated by IFN $\gamma$ via the JAK-STAT pathway, we exposed VL-17A cells to IFN $\gamma$ in the presence and absence of the selective JAK2 phosphorylation inhibitor, tyrphostin AG 490. This treatment prevented the enhancement of 


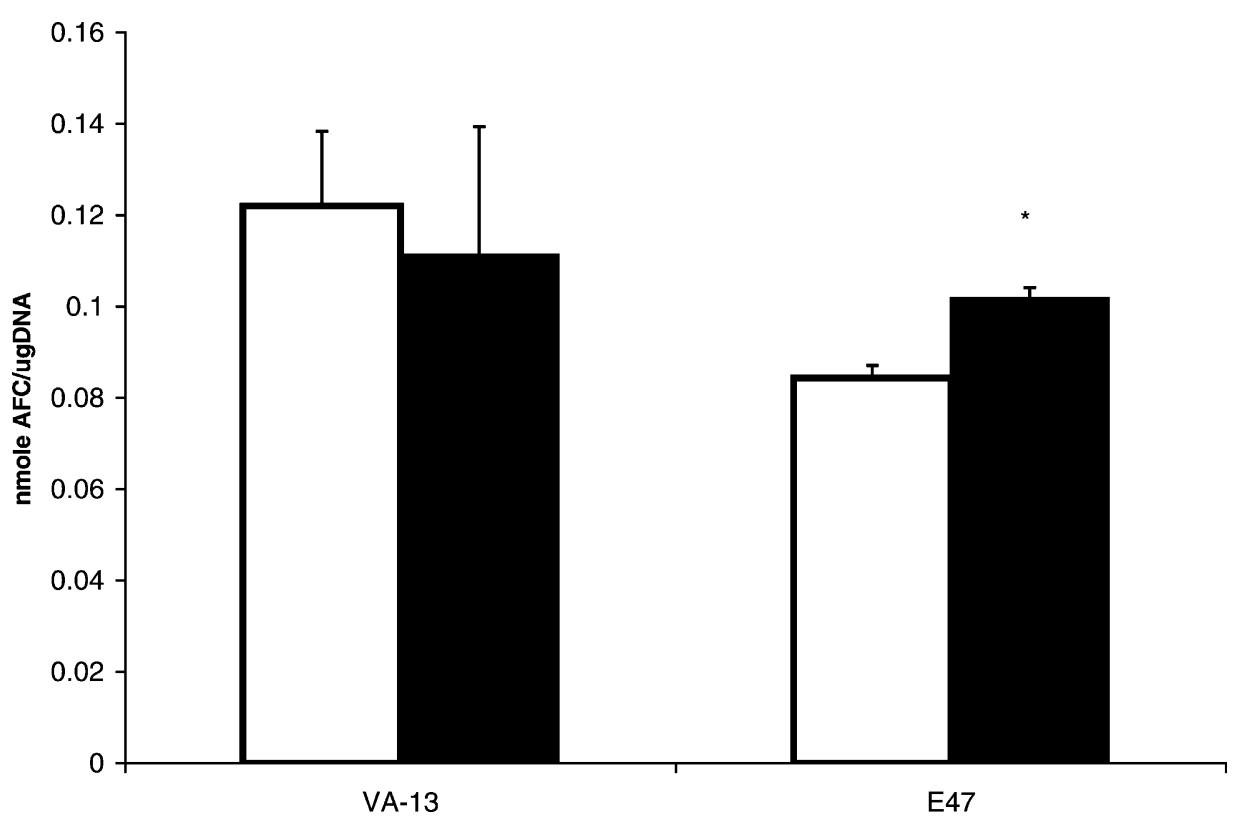

Fig. 4. Effects of IFN $\gamma$ on proteasome activity in VA-13 and E-47 cells. Cells were exposed or not to IFN $\gamma(10 \mathrm{ng} / \mathrm{mL})$ for $24 \mathrm{hr}$. The data represent mean values $( \pm \mathrm{SD})$ of three independent experiments (quadruplicate measurements in each), obtained after $6 \mathrm{hr}$ of incubation with FLF-AFC. Asterisk indicates significant difference between IFN $\gamma$-treated (dark bars) and untreated cells (open bars) at $P<0.05$.

proteasome activity as well as the decrease of CYP2E1 activity (Fig. 8), indicating that the JAK-STAT pathway is involved in both these processes.

We further tested the effects of ethanol on the transduction of IFN $\gamma$ signal via the JAK-STAT1 pathway using ethanol-metabolizing VL-17A cells and non-metabolizing Hep G2 cells. During the final $24 \mathrm{hr}$ interval of a $72 \mathrm{hr}$ ethanol exposure, cells were treated or not with IFN $\gamma$ (10 ng/mL), for $0,1,5$ and $24 \mathrm{hr}$. Both phosphorylated STAT1 (pSTAT1) and total STAT1 were determined in cell lysates by Western blot. As shown in Fig. 9, ethanol treatment decreased the pSTAT1/STAT1 ratio in Hep G2 cells by 1.5-2-fold compared with untreated cells after $1 \mathrm{hr}$ of IFN $\gamma$ exposure. By comparison, the pSTAT1/STAT1

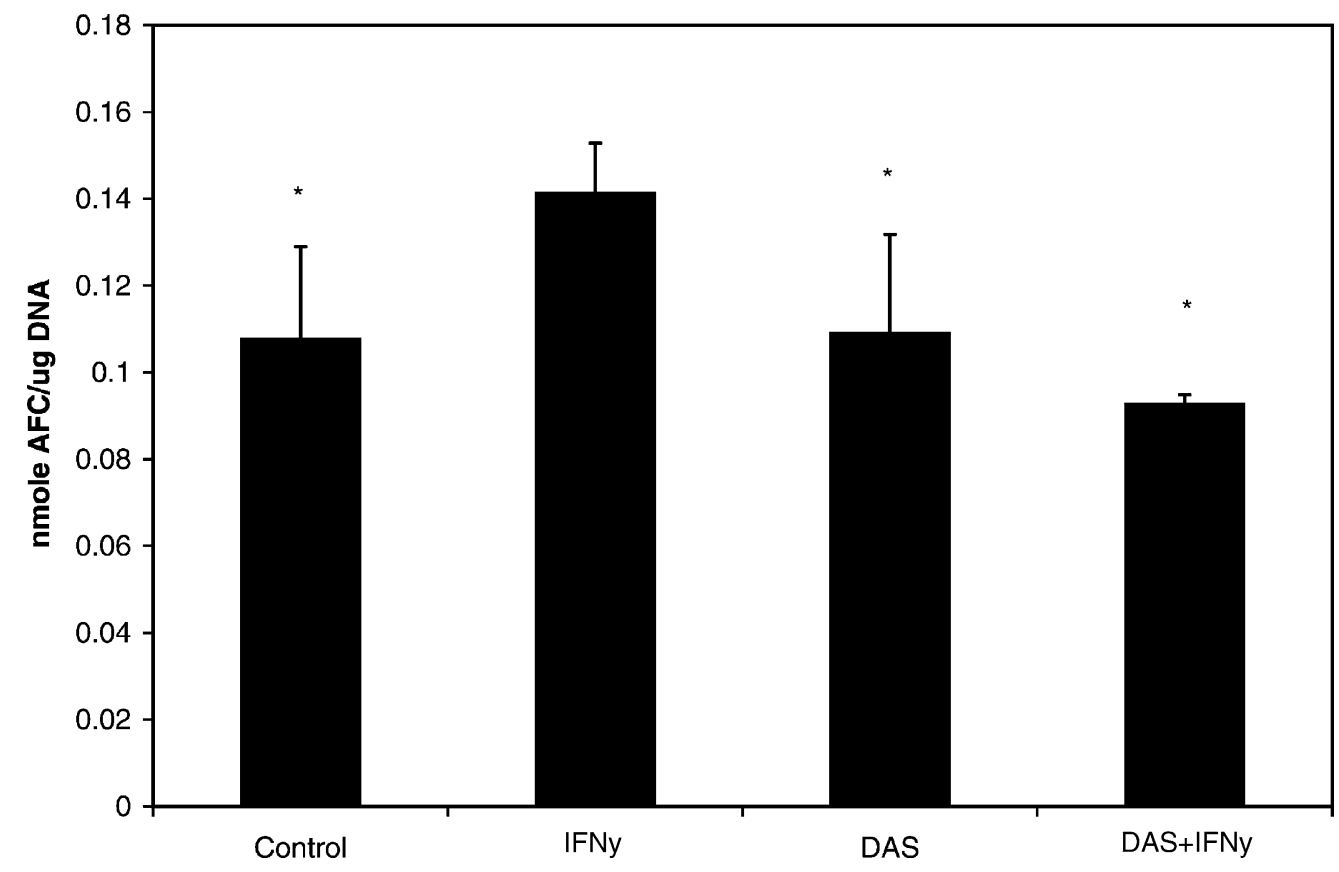

Fig. 5. The effects of diallyl sulfide (DAS) on IFN $\gamma$-activation of proteasome activity in VL-17A cells. VL-17A cells were treated or not with $10 \mu \mathrm{M}$ DAS, for $24 \mathrm{hr}$. The cells were then treated or not with IFN $\gamma(10 \mathrm{ng} / \mathrm{mL})$, in the presence or absence of DAS, for the next $24 \mathrm{hr}$. The data represent mean values $( \pm \mathrm{SD})$ of quadruplicate measurements from three independent experiments. An asterisk indicates that the value is significantly different from IFN $\gamma$-treated cells. 

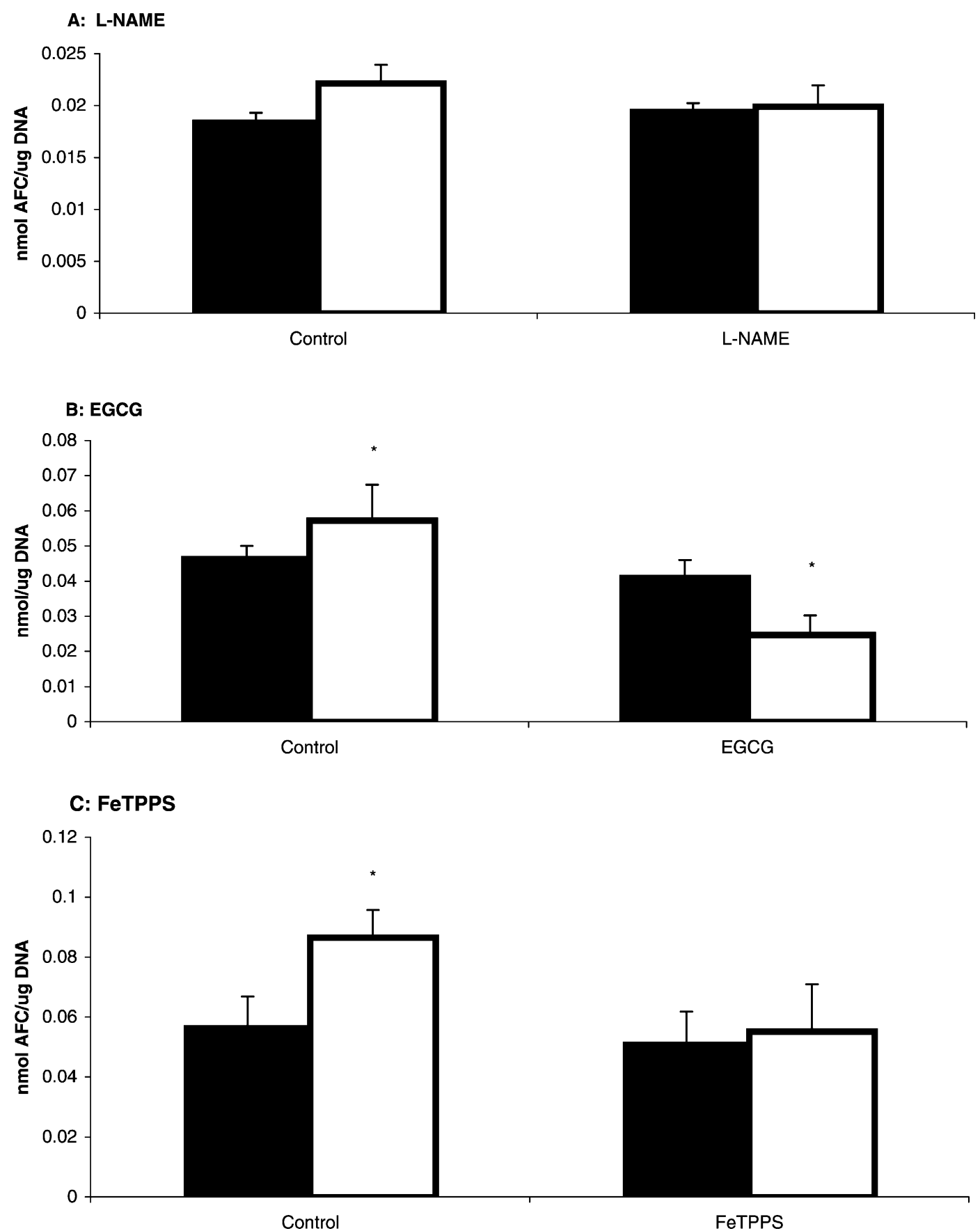

Fig. 6. The effects of L-NAME, EGCG and FeTPPS on IFN $\gamma$-mediated activation of proteasome in VL-17A cells. VL-17A cells were simultaneously treated with IFN $\gamma$ and with $300 \mu \mathrm{M}$ L-NAME (panel A), $200 \mu \mathrm{M}$ EGCG (panel B) or $10 \mu \mathrm{M}$ FeTPPS (panel C) for 24 hr, and proteasome activity was measured by FLF-AFC hydrolysis. Data are from one experiment (quadruplicate measurements). Two other experiments (not shown) had similar results and similar significant differences between IFN $\gamma$-untreated controls and IFN $\gamma$-treated cells. Mean values $( \pm \mathrm{SD})$ are shown from one experiment due to variability in basal activities of proteasome in the three experiments. A: L-NAME-treated cells; B: EGCG-treated cells; C: FeTPPS-treated cells. Asterisk indicates significant difference $(P<0.05)$ between IFN $\gamma$-untreated controls (dark bars) vs. IFN $\gamma$-treated cells (open bars).

ratio declined 6-7-fold in ethanol-treated VL-17A cells after $1 \mathrm{hr}$ of IFN $\gamma$ treatment. To further test whether STAT1 phosphorylation in VL-17A cells was affected by the products of ethanol metabolism, we treated cells for $72 \mathrm{hr}$ with both ethanol and 4-methylpyrazole (4MP), an inhibitor of ethanol metabolism. Treatment with 4MP prevented the ethanol-induced suppression of STAT1 phosphorylation in VL-17A cells (Fig. 10).

\section{Discussion}

The liver is routinely exposed to toxic agents, microbes and viruses arriving via the portal vein from the gastrointestinal tract. Such exposure can activate liver immune cells. Activated intrahepatic lymphocytes secrete IFN $\gamma$ and other cytokines in response to these stimuli, thus putting hepatocytes under continuous cytokine exposure. 


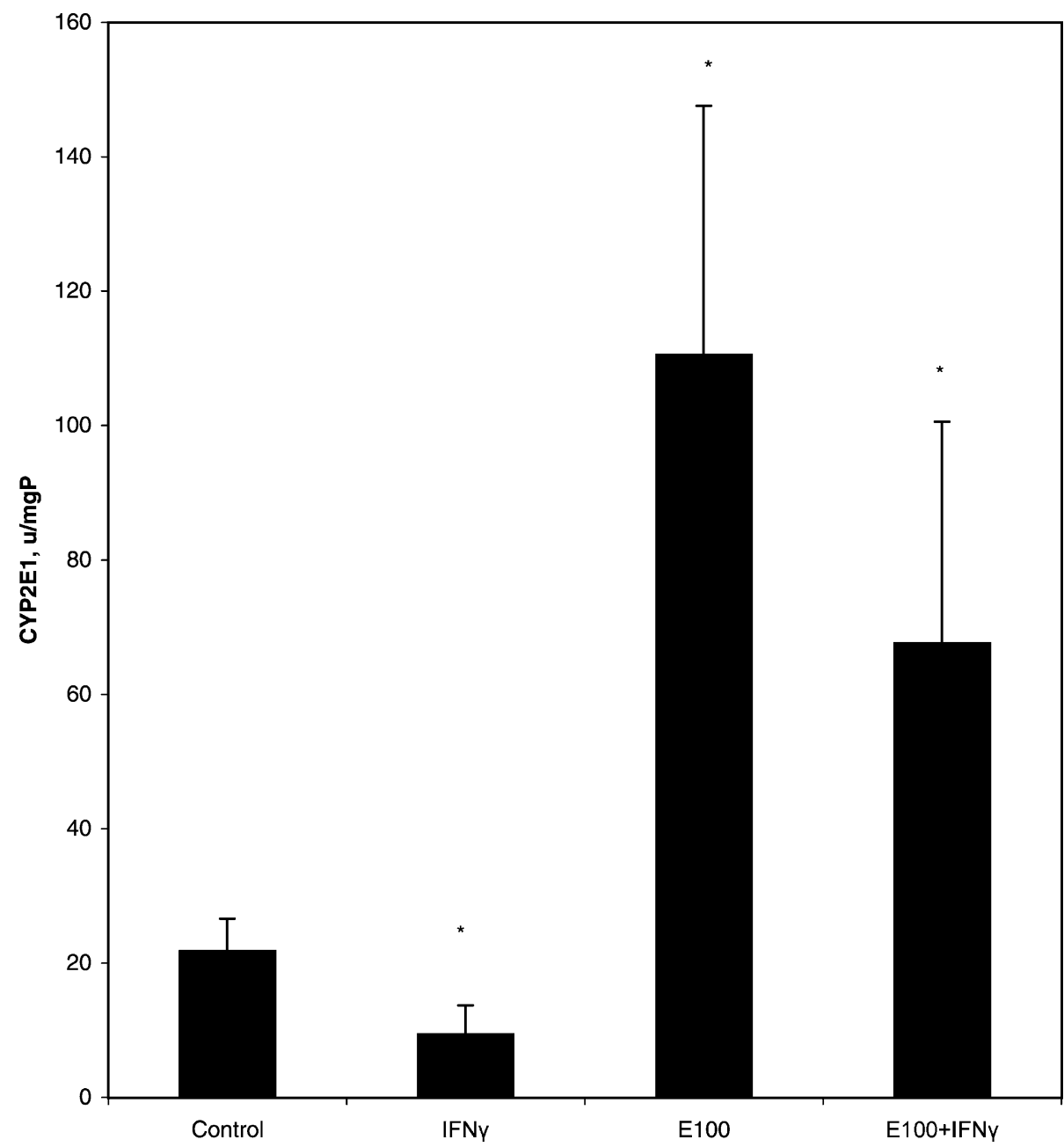

Fig. 7. The effects of IFN $\gamma$ and/or ethanol treatment on CYP2E1 activity in VL-17A cells. VL-17A cells were pre-treated or not with $100 \mathrm{mM}$ ethanol (E100) for $48 \mathrm{hr}$. IFN $\gamma$ was then added $(10 \mathrm{ng} / \mathrm{mL})$, and cells were incubated for an 24 additional hours. Data are mean values $( \pm$ SD) of five independent experiments. Asterisk indicates significant difference $(P<0.05)$ between control values (untreated cells) and ethanol or IFN $\gamma$ treatments.

Hepatocytes abundantly express proteasome activity and previous studies in vivo have shown that IFN $\gamma$ can regulate this activity in liver tissue [36]. However, it is not clear whether IFN $\gamma$ specifically affects proteasome activity in hepatocytes or in intrahepatic immune cells in both. In this investigation, using a liver-derived culture system, we sought to determine whether IFN $\gamma$ altered proteasome activity in cultured recombinant Hep G2 cells, which stably express the ethanol-metabolizing enzymes, CYP2E1 and ADH. Because liver cells are the primary sites of ethanol oxidation, we also explored the possibility that any IFN $\gamma$ modulation of proteasome activity as well as the transduction of IFN $\gamma$ signals in these cells may be altered by ethanol or its metabolism.

In this study, IFN $\gamma$ enhanced proteasome chymotrypsinlike activity in recombinant Hep G2 cells. The kinetics of this response showed an elevation in enzyme activity as early as $4 \mathrm{hr}$ and which remained elevated at the same level $24 \mathrm{hr}$ after exposure to the cytokine. These results indicate that the IFN $\gamma$-elicited enhancement in enzyme activity was probably not the result of cytokine-induced de novo proteasome synthesis, as the enzyme has a very slow rate of turnover $t_{1 / 2}=12-15$ days in rat liver [37]. Rather, the rapidity of this increase in response to IFN $\gamma$ treatment appeared to reflect changes in the activity of the existing enzyme.

Enhancement of proteasome chymotryspin-like activity in Hep G2-derived cells depended upon the expression of CYP2E1 because only VL-17A cells $\left(\mathrm{ADH}^{+} / \mathrm{CYP} 2 \mathrm{E} 1^{+}\right)$ and E-47 cells $\left(\mathrm{CYP} 2 \mathrm{E} 1^{+}\right)$showed this response to IFN $\gamma$. Additionally, the degree of IFN $\gamma$-mediated activation of the proteasome was positively associated with the basalCYP2E1 activity in VL-17A cells. Furthermore, when we treated the cells with IFN $\gamma$ in the presence of CYP2E1 inhibitor DAS, IFN $\gamma$ no longer increased proteasome activity. Thus, CYP2E1 catalysis was necessary for IFN $\gamma$-mediated proteasome activation, leading us to suggest that one or more products generated by CYP2E1 influence(s) proteasome activity. It is well known that CYP2E1 is a loosely coupled enzyme that can generate superoxide and other reactive species even in the absence of substrate $[38,39]$.

In addition to CYP2E1 catalysis, nitric oxide generation was also required for proteasome activation by IFN $\gamma$. This 

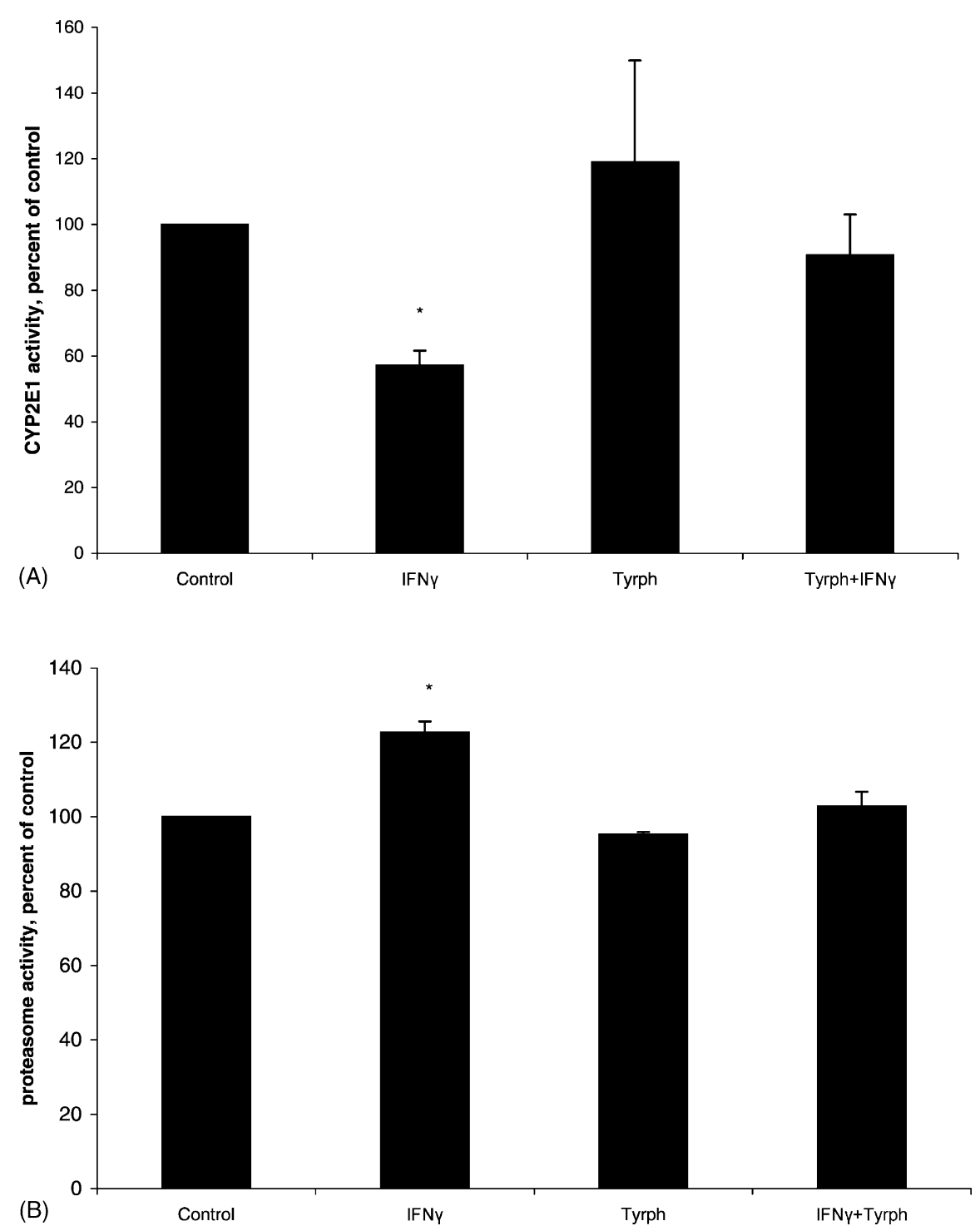

Fig. 8. The effects of tyrphostin AG 490 on IFN $\gamma$-mediated effects on CYP2E1 and proteasome in VL-17A cells. Cells were treated or not with $1 \mu \mathrm{M}$ tyrphostin AG 490 for $1 \mathrm{hr}$. IFN $\gamma(10 \mathrm{ng} / \mathrm{mL}$ ) was added, and cells were incubated for additional $24 \mathrm{hr}$. CYP2E1 activity (panel A) was assayed in microsome fractions of cell lysates proteasome activity (panel B) assayed in situ by FLF-AFC hydrolysis. Because of intra-experimental variation in enzyme activity, data are expressed as a percent of untreated control from three independent experiments. Statistical significance was assessed by a mixed effect ANOVA model, in which pair wise comparisons were made among the various treatment groups. Asterisk indicates that the value is significantly different $(P<0.05)$ from IFN $\gamma$-treated cells.

was indicated by the blockage of IFN $\gamma$-mediated proteasome activation by L-NAME and EGCG. Both these agents inhibit NO formation. Furthermore, our time-course experiments (Fig. 1) indicated that proteasome activity began to rise after $4 \mathrm{hr}$ of IFN $\gamma$ treatment. This time period is consistent with that necessary for induction of iNOS by IFN $\gamma$, previously seen in macrophages [40]. Therefore, we propose that VL-17A cells with higher basal CYP2E1 activities had a greater capacity to produce superoxide from CYP2E1. NO, that was generated by iNOS, following IFN $\gamma$ treatment reacted with superoxide to form peroxynitrite, which, in turn, increased proteasome activity. Furthermore, our results showed that when VL-17A cells were exposed to the peroxynitrite scavenger, FeTPPS, this agent also prevented proteasome activation by the cytokine. These latter findings further uphold our suggestion that the proximal agent responsible for proteasome activation is peroxynitrite.

Peroxynitrite reacts with tyrosine residues in proteins, forming nitrated proteins [41]. Previous studies have shown that mild modification of the enzyme aconitase with low concentrations of peroxynitrite inactivates this enzyme [42]. In light of these and similar findings [43] we thought it unlikely that metabolically derived peroxynitrite would activate the proteasome in VL-17A cells. To test this further, we have recently conducted experiments in vitro, using purified preparations of the $20 \mathrm{~S}$ proteasome exposed to low concentrations of the peroxynitrite donor 3-morpholinosydnonimine (SIN-1). Compared with untreated enzyme, low SIN-1 concentrations enhanced proteasome chymotrypsin-like activity by as much as 2 -fold. However, higher 


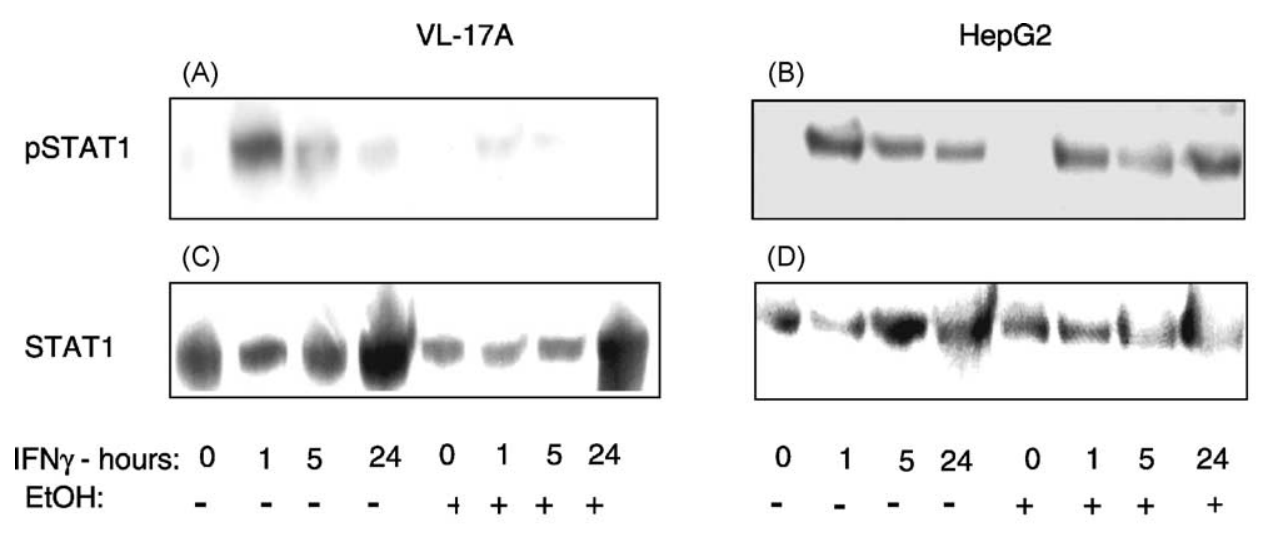

(E)

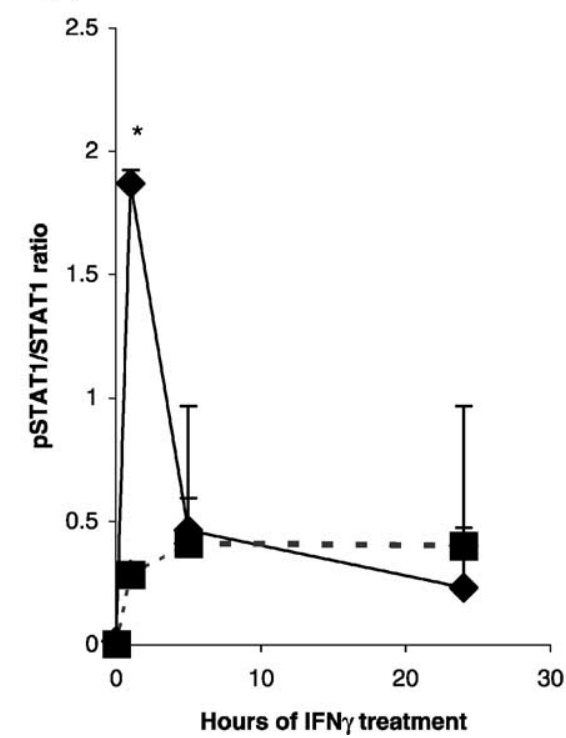

(F)

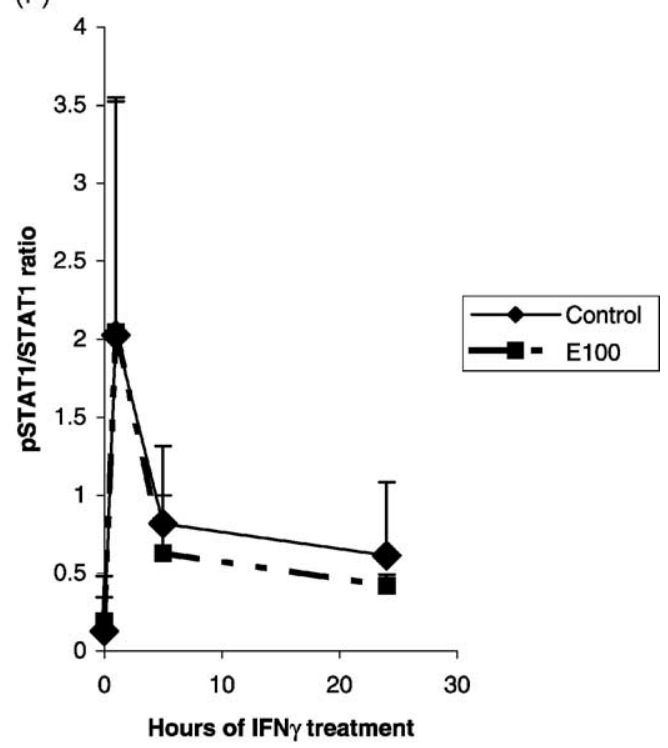

Fig. 9. Effect of ethanol treatment on STAT1 phosphorylation in VL-17A and Hep G2 cells following exposure to IFN $\gamma$. Cells were treated or not with $100 \mathrm{mM}$ ethanol for $72 \mathrm{hr}$ in serum-free DMEM or left untreated. During the final $24 \mathrm{hr}$ of ethanol exposure cells were treated or not with IFN $\gamma$ ( $10 \mathrm{ng} / \mathrm{mL}$ ) for $0,1,5,24 \mathrm{hr}$. Cell lysates were subjected to SDS-PAGE/Western blotting (30 $\mu \mathrm{g}$ protein/well). Data shown from Western blot are from one representative experiment (out of a total of three with similar results). Panels A and B: phosphorylated STAT1 (pSTAT1) levels after 0-24 hr stimulation with IFN $\gamma$, in ethanol pretreated and untreated VL-17A (panel A) and Hep G2 (panel B) cells. Panels C and D: total STAT1 levels (0-24 hr in VL-17A cells (panel C) and Hep G2 cells (panel D) treated with IFN $\gamma$, untreated vs. ethanol-treated). Panel E: pSTAT1/STAT1 ratios in VL-17A cells (mean \pm SD, three experiments) Asterisk indicates that value is significant $(P<0.05)$ in ethanol-untreated cells vs. ethanol-treated. Panel F: pSTAT1/STAT1 ratio in Hep G2 cells (mean $\pm \mathrm{SD}$, three experiments).

concentrations of SIN-1 caused its inactivation. ${ }^{2}$ These observations further support our view that peroxynitrite can activate the same catalytic activity of the proteasome that was measured in VL-17A cells, but that such activation is limited and can eventually result in the loss of proteasome activity when the levels of the oxidant become excessive.

In view of these latter observations, it is noteworthy that after $24 \mathrm{hr}$ of IFN $\gamma$ treatment, CYP2E1 activity went down. This IFN $\gamma$-dependent decrease in CYP2E1 activity confirms the results of earlier studies in hepatocytes showing that IFN $\gamma$ decreases a number of $\mathrm{P} 450$ isoenzymes by suppressing their mRNA levels, thereby decreasing their intracellular content [35]. This decrease also occurs at least partly via nitric oxide inhibition of CYP2E1 [44]. Thus, we suggest that in VL-17A cells IFN $\gamma$-enhances production of

\footnotetext{
${ }^{2}$ Osna, unpublished results.
}

NO, which reacts with superoxide to form peroxynitrite. The latter, which is produced at low concentrations, in turn activates the proteasome. At the same time, NO suppresses CYP2E1 catalysis thereby limiting the quantity of superoxide generated by CYP2E1 and thus limiting the degree of proteasome activation.

Proteasome activity declined after treatment of cells with $100 \mathrm{mM}$ ethanol. These results confirm our previous results reported recently and can be attributed to ethanol metabolism, since ethanol-elcited proteasome inactivation can be prevented by inhibition of ethanol metabolism (see Footnote 1). We do not know the mechanism responsible for the decline in proteasome activity, but we speculate that the induced levels of CYP2E1 may generate higher levels of oxidants that contribute to proteasome inactivation. One of these oxidants may indeed be peroxynitrite, as Baraona et al. recently demonstrated that chronic ethanol 
VL-17A

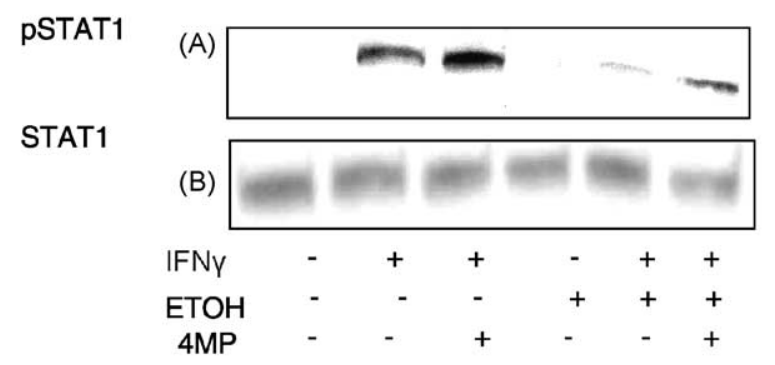

(E)

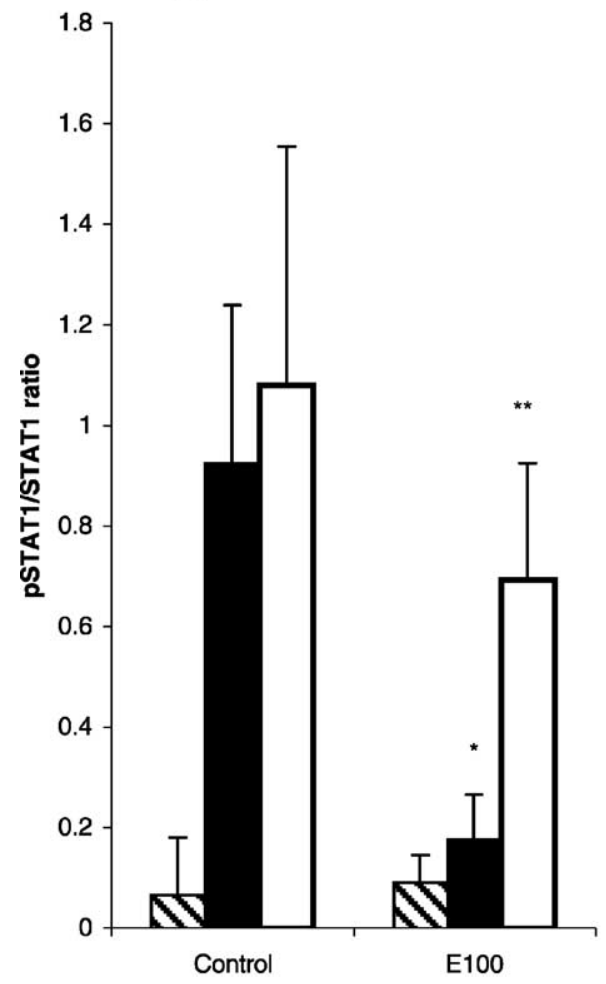

HepG2
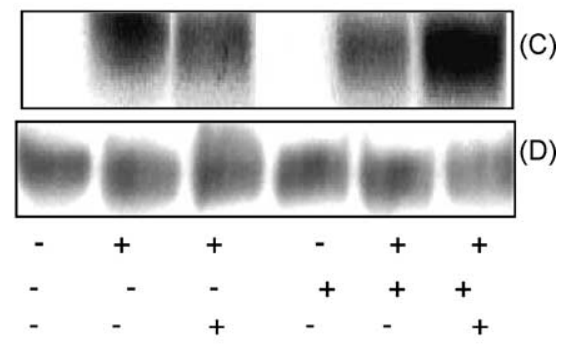

$(\mathrm{F})$

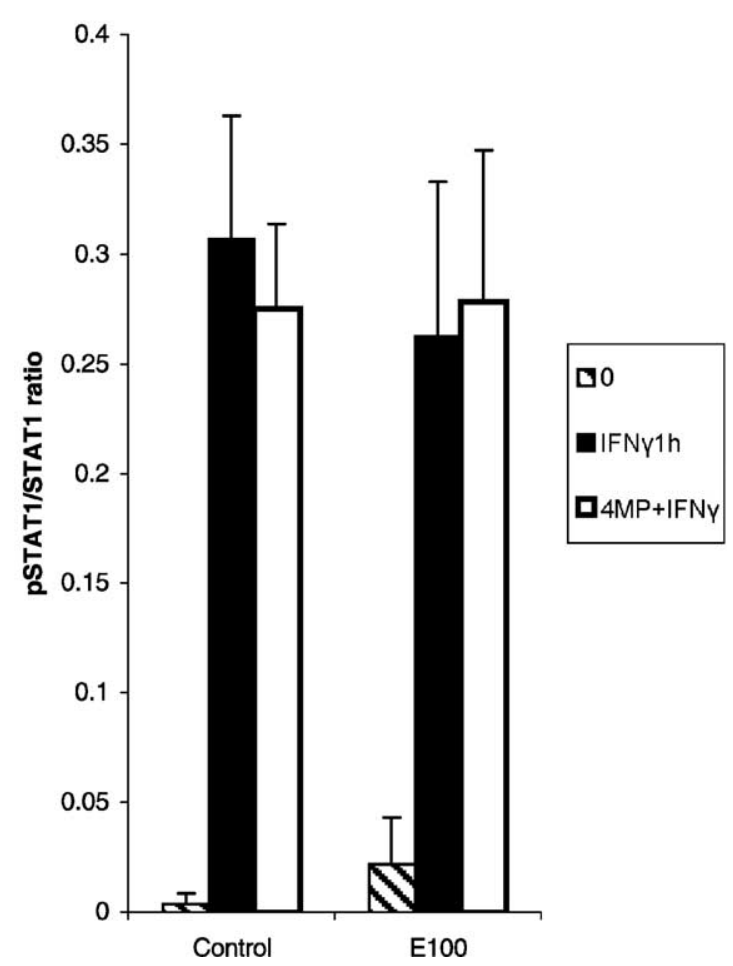

Fig. 10. Effects of ethanol with or without 4-methylpyrazole (4-MP) on STAT1 phosphorylation in VL-17A and Hep G2 cells. Cells were treated or not with $100 \mathrm{mM}$ ethanol for $72 \mathrm{hr}$ in the presence or absence of $5 \mathrm{mM}$ 4-MP and then exposed to IFN $\gamma$ for $1 \mathrm{hr}$. Data are representative from one of two experiments. Phosphorylated STAT1 (pSTAT1) in VL-17A cells (panel A) and Hep G2 cells (panel C) treated as indicated. Total STAT1 in VL-17A cells (panel B) and Hep G2 cells (panel D) treated as indicated. The pSTAT1/STAT1 ratios are presented in panel E (VL-17A cells) and panel F (Hep G2 cells) as mean values of three experiments. Asterisk indicates a significant difference $(P<0.05)$ in pSTAT1/STAT1 ratio between control and ethanol-treated cells, both exposed to IFN $\gamma$. Asterisks indicate a significant difference $(P<0.05)$ in pSTAT1/STAT1 ratio between 4MP-treated and -untreated cells exposed to ethanol and IFN $\gamma$.

administration enhances iNOS activity and the formation of peroxynitrite in rat liver [45].

When cells were exposed to ethanol, neither CYP2E1, nor the proteasome was affected by IFN $\gamma$. These results indicated that IFN $\gamma$-mediated effects on CYP2E1 catalysis and proteasome activity were modulated via the same signal transduction pathway. This conclusion is supported by the observed prevention by tyrphostin AG 490 of IFN $\gamma$ mediated proteasome activation and decreased CYP2E1 activity. The results lead us to suggest that the regulation of these enzymes is downstream from JAK-STAT1 signaling.

Exposure of VL-17A cells to $100 \mathrm{mM}$ ethanol prior to IFN $\gamma$ treatment prevented STAT1 phosphorylation in ethanol-metabolizing VL-17A cells. Nguyen et al. [46] reported an impaired IFN $\gamma$-activated phosphorylation of STAT1 after acute ethanol $(30 \mathrm{~min})$ treatment of hepatocytes. However, these authors found no alteration in STAT1 phosphorylation in ethanol-treated Hep G2 or in $\mathrm{ADH}^{+}$ VA-13 cells [47]. They concluded that ethanol-induced suppression of STAT1 phosphorylation could not be attributed to ethanol metabolism. In contrast, our results indicated that during ethanol exposure, VL-17A cells, but not Hep G2 cells exhibited a prominent decrease in STAT1 phosphorylation. Furthermore, the prevention of ethanol metabolism by treatment with 4-MP blocked the ethanolelicited reduction of STAT1 phosphorylation. Thus, we conclude that one or more products of ethanol metabolism blocks IFN $\gamma$ signal transduction in VL-17A cells. 


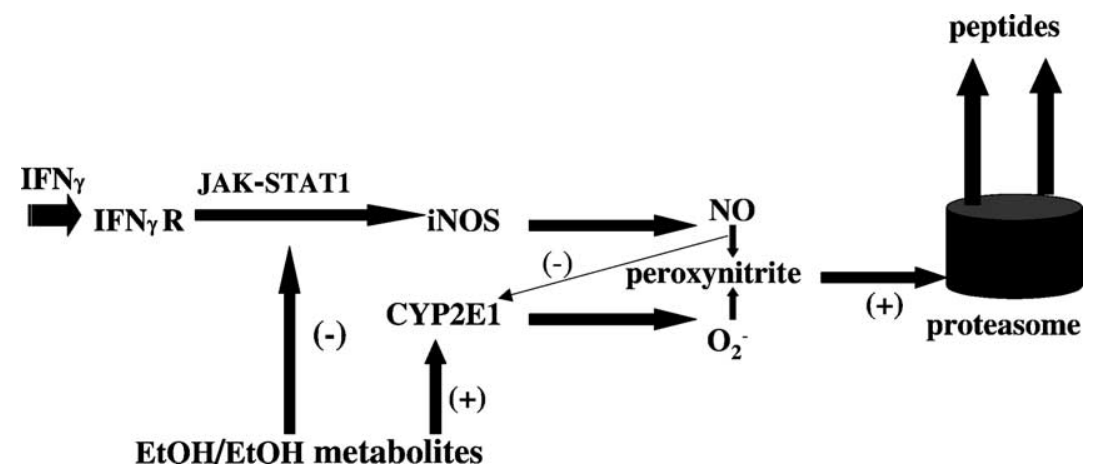

Fig. 11. Hypothetical scheme depicting IFN $\gamma$-mediated activation of proteasome in recombinant Hep G2 cells. IFN $\gamma$ binds to IFN $\gamma$ R and initiates JAKSTAT1 signal transduction. iNOS is activated via JAK-STAT1 pathway to catalyze NO formation. CYP2E1 catalyzes superoxide formation. The reaction product of NO and superoxide, peroxynitrite, at low physiological concentrations activates the proteasome. In the presence of ethanol CYP2E1 activity is increased, but ethanol metabolites prevent STAT1 phosphorylation, which blocks IFN $\gamma$ signal transduction. Thus, proteasome is not activated by IFN $\gamma$ in ethanol-treated CYP2E1-expressing cells.

Currently, the identity of those inhibitory products is not clear. In preliminary experiments (not shown) we have observed that ethanol prevents STAT1 phosphorylation in VA-13 cells, but not in E-47 cells, indicating that acetaldehyde has a role in blocking STAT1 phosphorylation. When incubated in the presence of $100 \mathrm{mM}$ ethanol, VL-17A cells generate $>200 \mu \mathrm{M}$ acetaldehyde in the medium. ${ }^{3}$ Acetaldehyde is known to activate the protein kinase $\mathrm{C}$ (PKC) pathway [48], which, in turn, down-regulates JAK-STATs [47]. It was recently demonstrated that malondialdehydeacetaldehyde-protein (MAA) adducts also activate the PKC pathway [49]. The formation of these secondary ethanolderived products may also contribute to the ethanol-induced blockade of STAT1 phosphorylation. Thus, these and other mechanisms remain to be investigated.

In Fig. 11, we present a proposed mechanism of proteasome activation in response to IFN $\gamma$ and how this response may be regulated by ethanol.

In summary, our findings indicate that enhancement of proteasome activity occurred in IFN $\gamma$-treated Hep G2 cells that express CYP2E1. This enhancement may be related to the production of peroxynitrite, generated by CYP2E1catalysis $\left(\mathrm{O}_{2}{ }^{-}\right)$and the iNOS activity (NO). Both proteasome activity and CYP2E1 activity are regulated by IFN $\gamma$ via the JAK-STAT1 pathway. Ethanol metabolism prevents phosphorylation of STAT1 making the proteasome in VL17A cells unresponsive to IFN $\gamma$-mediated effects.

\section{Acknowledgments}

We thank Dr. Charles Kuszynski and Linda Wilkie for performing flow cytometry for detection of IFN $\gamma \mathrm{R} \alpha$. We are pleased to acknowledge the valuable technical assistance of Jimmie L. Nelson. We thank Dr. Julie Stoner, of the Dept of Preventive and Societal Medicine of the UNMC, for performing some of the statistical analyses. This study was

\footnotetext{
${ }^{3}$ Donohue, unpublished results.
}

supported by Medical Research Funds from the Department of Veterans Affairs and VA Alcohol Research Center.

\section{References}

[1] Chen Z, Hagler J, Palombella VJ, Melandri F, Scherer D, Ballard D, Maniatis T. Signal-induced site-specific phosphorylation targets I kappa B alpha to the ubiquitin-proteasome pathway. Genes Dev 1995;9(13):1586-97.

[2] Musti AM, Treier M, Peverali FA, Bohmann D. Differential regulation of c-Jun and JunD by ubiquitin-dependent protein degradation. Biol Chem 1996;377(10):619-24.

[3] Kim TK, Maniatis T. Regulation of interferon-gamma-activated STAT1 by the ubiquitin-proteasome pathway. Science 1996; 273(5282):1717-9.

[4] Mezey E, Rennie-Tankersley L, Potter JJ. Liver alcohol dehydrogenase is degraded by the ubiquitin-proteasome pathway. Biochem Biophys Res Commun 2001;285(3):644-8.

[5] Emanuele S, Calvaruso G, Lauricella M, Giuliano M, Bellavia G, D'Anneo A, Vento R, Tesoriere G. Apoptosis induced in hepatoblastoma HepG2 cells by the proteasome inhibitor MG132 is associated with hydrogen peroxide production, expression of Bcl-XS and activation of caspase-3. Int J Oncol 2002;21(4):857-65.

[6] Naujokat C, Hoffmann S. Role and function of the $26 \mathrm{~S}$ proteasome in proliferation and apoptosis. Lab Invest 2002;82(8):965-80.

[7] Bose S, Brooks P, Mason GG, Rivett AJ. gamma-Interferon decreases the level of $26 \mathrm{~S}$ proteasomes and changes the pattern of phosphorylation. Biochem J 2001;353(Pt 2):291-7.

[8] Van den Eynde BJ, Morel S. Differential processing of class-Irestricted epitopes by the standard proteasome and the immunoproteasome. Curr Opin Immunol 2001;13(2):147-53.

[9] Yang Y, Jooss KU, Su Q, Ertl HC, Wilson JM. Immune responses to viral antigens vs. transgene product in the elimination of recombinant adenovirus-infected hepatocytes in vivo. Gene Ther 1996;3(2):137-44.

[10] Neumann H, Medana IM, Bauer J, Lassmann H. Cytotoxic T lymphocytes in autoimmune and degenerative CNS diseases. Trends Neurosci 2002;25(6):313-9.

[11] Lieber CS. Alcohol, protein metabolism, and liver injury. Gastroenterology 1980;79(2):373-90.

[12] Clemens DL, Forman A, Jerrells TR, Sorrell MF, Tuma DJ. Relationship between acetaldehyde levels and cell survival in ethanol-metabolizing hepatoma cells. Hepatology 2002;35(5):1196-204.

[13] Wu D, Cederbaum AI. Expression of cytochrome P4502E1 in rat fetal hepatocyte culture. Mol Pharmacol 1996;49(5):802-7. 
[14] Lowe J, Blanchard A, Morrell K, Lennox G, Reynolds L, Billett M, Landon M, Mayer RJ. Ubiquitin is a common factor in intermediate filament inclusion bodies of diverse type in man, including those of Parkinson's disease, Pick's disease, and Alzheimer's disease, as well as Rosenthal fibres in cerebellar astrocytomas, cytoplasmic bodies in muscle, and Mallory bodies in alcoholic liver disease. J Pathol 1988;155(1):9-15.

[15] Bardag-Gorce F, French BA, Lue YH, Nguyen V, Wan YJ, French SW. Mallory bodies formed in proteasome-depleted hepatocytes: an immunohistochemical study. Exp Mol Pathol 2001;70(1):7-18.

[16] Donohue Jr TM, Zetterman RK, Zhang-Gouillon ZQ, French SW. Peptidase activities of the multicatalytic protease in rat liver after voluntary and intragastric ethanol administration. Hepatology 1998;28(2):486-91.

[17] Fataccioli V, Andraud E, Gentil M, French SW, Rouach H. Effects of chronic ethanol administration on rat liver proteasome activities: relationship with oxidative stress. Hepatology 1999;29(1):14-20.

[18] Bardag-Gorce F, Yuan QX, Li J, French BA, Fang C, IngelmanSundberg M, French SW. The effect of ethanol-induced cytochrome p4502E1 on the inhibition of proteasome activity by alcohol. Biochem Biophys Res Commun 2000;279(1):23-9.

[19] Fruh K, Yang Y. Antigen presentation by MHC class I and its regulation by interferon gamma. Curr Opin Immunol 1999;11(1): $76-81$.

[20] Boes B, Hengel H, Ruppert T, Multhaup G, Koszinowski UH, Kloetzel PM. Interferon gamma stimulation modulates the proteolytic activity and cleavage site preference of $20 \mathrm{~S}$ mouse proteasomes. J Exp Med 1994;179(3):901-9.

[21] York IA, Goldberg AL, Mo XY, Rock KL. Proteolysis and class I major histocompatibility complex antigen presentation. Immunol Rev 1999;172:49-66.

[22] Osna N, Clemens D, Donohue T. Ethanol reciprocally regulates CYP2E1 and proteasome activities in double-recombinant HepG2 cells treated with interferon gamma. Alcohol: Clin Exp Res 2002;26:60A (Abstract No. 331).

[23] Osna N, Clemens D, Donohue Jr TM. Ethanol suppresses interferon gamma-mediated activation of the proteasome by preventing STAT1 phosphorylation in human recombinant Hep G2 cells. Hepatology 2002;36(4 pt(2)):334A (Abstract No. 684).

[24] Donohue TM, Clemens DL, Galli A, Crabb D, Nieto N, Kato J, Barve SS. Use of cultured cells in assessing ethanol toxicity and ethanolrelated metabolism. Alcohol: Clin Exp Res 25 (2001) (5 Suppl ISBRA) 87S-93S.

[25] Crow KE, Cornell NW, Veech RL. The rate of ethanol metabolism in isolated rat hepatocytes. Alcohol Clin Exp Res 1977;1(1):43-50.

[26] Clemens DL, Halgard CM, Miles RR, Sorrell MF, Tuma DJ. Establishment of a recombinant hepatic cell line stably expressing alcohol dehydrogenase. Arch Biochem Biophys 1995;321(2):311-8.

[27] Koop DR. Hydroxylation of $p$-nitrophenol by rabbit ethanol-inducible cytochrome P-450 isozyme 3a. Mol Pharmacol 1986;29(4):399-404.

[28] Chen Q, Galleano M, Cederbaum AI. Cytotoxicity and apoptosis produced by arachidonic acid in HepG2 cells overexpressing human cytochrome P-4502E1. Alcohol Clin Exp Res 1998;22(4):782-4.

[29] Bradford MM. A rapid and sensitive method for the quantitation of microgram quantities of protein utilizing the principle of protein-dye binding. Anal Biochem 1976;72:248-54.

[30] Hamel FG, Bennett RG, Harmon KS, Duckworth WC. Insulin inhibition of proteasome activity in intact cells. Biochem Biophys Res Commun 1997;234(3):671-4.

[31] Labarca C, Paigen K. A simple, rapid and sensitive DNA assay procedure. Anal Biochem 1980;102(2):344-52.

[32] Wu D, Cederbaum AI. Ethanol-induced apoptosis to stable HepG2 cell lines expressing human cytochrome P-4502E1. Alcohol Clin Exp Res 1999;23(1):67-76.
[33] Wink DA, Mitchell JB. Chemical biology of nitric oxide: insights into regulatory, cytotoxic, and cytoprotective mechanisms of nitric oxide. Free Radic Biol Med 1998;25(4/5):434-56.

[34] Matata BM, Galinanes M. Peroxynitrite is an essential component of cytokines production mechanism in human monocytes through modulation of nuclear factor-kappa B DNA binding activity. J Biol Chem 2002;277(3):2330-5.

[35] Abdel-Razzak Z, Loyer P, Fautrel A, Gautier JC, Corcos L, Turlin B, Beaune P, Guillouzo A. Cytokines down-regulate expression of major cytochrome P-450 enzymes in adult human hepatocytes in primary culture. Mol Pharmacol 1993;44(4):707-15.

[36] Khan S, van den Broek M, Schwarz K, de Giuli R, Diener PA, Groettrup M. Immunoproteasomes largely replace constitutive proteasomes during an antiviral and antibacterial immune response in the liver. J Immunol 2001;167(12):6859-68.

[37] Tanaka K, Ichihara A. Half-life of proteasomes (multiprotease complexes) in rat liver. Biochem Biophys Res Commun 1989;159(3): 1309-15.

[38] Nieto N, Friedman SL, Greenwel P, Cederbaum AI. CYP2E1mediated oxidative stress induces collagen type I expression in rat hepatic stellate cells. Hepatology 1999;30(4):987-96.

[39] Nieto N, Greenwel P, Friedman SL, Zhang F, Dannenberg AJ, Cederbaum AI. Ethanol and arachidonic acid increase alpha 2(I) collagen expression in rat hepatic stellate cells overexpressing cytochrome P450 2E1. Role of $\mathrm{H} 2 \mathrm{O} 2$ and cyclooxygenase-2. J Biol Chem 2000;275(26):20136-45.

[40] Calleja C, Eeckhoutte C, Dacasto M, Larrieu G, Dupuy J, Pineau T, Galtier P. Comparative effects of cytokines on constitutive and inducible expression of the gene encoding for the cytochrome P450 3A6 isoenzyme in cultured rabbit hepatocytes: consequences on progesterone 6beta-hydroxylation. Biochem Pharmacol 1998;56(10):1279-85.

[41] Alvarez B, Rubbo H, Kirk M, Barnes S, Freeman BA, Radi R. Peroxynitrite-dependent tryptophan nitration. Chem Res Toxicol 1996;9(2):390-6.

[42] Grune T, Blasig IE, Sitte N, Roloff B, Haseloff R, Davies KJ. Peroxynitrite increases the degradation of aconitase and other cellular proteins by proteasome. J Biol Chem 1998;273(18):10857-62.

[43] Radi R, Beckman JS, Bush KM, Freeman BA. Peroxynitrite-induced membrane lipid peroxidation: the cytotoxic potential of superoxide and nitric oxide. Arch Biochem Biophys 1991;288(2):481-7.

[44] Donato MT, Guillen MI, Jover R, Castell JV, Gomez-Lechon MJ. Nitric oxide-mediated inhibition of cytochrome $\mathrm{P} 450$ by interferon-gamma in human hepatocytes. J Pharmacol Exp Ther 1997;281(1):484-90.

[45] Baraona E, Zeballos GA, Shoichet L, Mak KM, Lieber CS. Ethanol consumption increases nitric oxide production in rats, and its peroxynitrite-mediated toxicity is attenuated by polyenylphosphatidylcholine. Alcohol Clin Exp Res 2002;26(6):883-9.

[46] Nguyen VA, Chen J, Hong F, Ishac EJ, Gao B. Interferons activate the p42/44 mitogen-activated protein kinase and JAK-STAT (Janus kinasesignal transducer and activator transcription factor) signalling pathways in hepatocytes: differential regulation by acute ethanol via a protein kinase C-dependent mechanism. Biochem J 2000;349(Pt 2):427-34.

[47] Chen J, Clemens DL, Cederbaum AI, Gao B. Ethanol inhibits the JAKSTAT signaling pathway in freshly isolated rat hepatocytes but not in cultured hepatocytes or HepG2 cells: evidence for a lack of involvement of ethanol metabolism. Clin Biochem 2001;34(3):203-9.

[48] Domenicotti C, Paola D, Lamedica A, Ricciarelli R, Chiarpotto E, Marinari UM, Poli G, Melloni E, Pronzato MA. Effects of ethanol metabolism on PKC activity in isolated rat hepatocytes. Chem Biol Interact 1996;100(2):155-63.

[49] Kharbanda KK, Shubert KA, Wyatt TA, Sorrell MF, Tuma DJ. Effect of malondialdehyde-acetaldehyde-protein adducts on the protein kinase C-dependent secretion of urokinase-type plasminogen activator in hepatic stellate cells. Biochem Pharmacol 2002;63(3):553-62. 